\title{
Stabilitas Hasil dan Gangguan Penyakit pada Enam Genotipe Tomat di bawah Naungan
}

\author{
Yield Stability and Disease Incident on Six Tomato Genotypes Under Shading \\ Zulfa Ulinnuha ${ }^{1}$, Muhammad Ahmad Chozin ${ }^{2}$, dan Edi Santosa ${ }^{2 *}$ \\ Diterima 05 Maret 2018/Disetujui 04 Februari 2019
}

\begin{abstract}
Tomato becomes important as under-storey crop in agroforestry in Indonesia. However, farmers claim that there is yield reduction under such system. Hence, six tomato genotypes were planted under 50\% reduced sunshine and full sunshine as control using randomized block nested design with genotype as main plot. The study was carried out in December 2016 to March 2017 at Cikarawang Experimental Farm, IPB Bogor. Research aimed to evaluate the production stability of tomato genotypes under shading treatment. Results showed that $50 \%$ shading affected tomato production and disease incident. Number of collected-fruit was $15-60 \%$ higher under $50 \%$ shading except for Apel Belgia and Tora genotypes that tended to decrease. Incident of gemini virus decreased by $80 \%$ and its severity decreased by $70 \%$ under $50 \%$ shading. However, $50 \%$ shading reduced tomato yield at rate $24.1 \%$ in each harvesting cycle due to a tendency on reduction on individual fruit size, irrespective genotypes. Present study demonstrated that genotype and disease incident determined tomato yield under shading. It needs further evaluation on the cause of low disease infection under $50 \%$ shading.
\end{abstract}

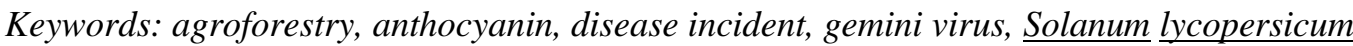

\begin{abstract}
ABSTRAK
Tomat sering ditanam sebagai sayuran pada sistem agroforestri, namun ada keluhan petani terkait fluktuasi produksi buah yang dihasilkan pada sistem tersebut. Oleh karena itu, produksi enam genotipe tomat dibandingkan antara naungan $0 \%$ dan 50\% menggunakan rancangan acak kelompok tersarang dengan tingkat naungan sebagai petak utama pada Desember 2016 sampai Maret 2017 di Kebun Percobaan Cikarawang IPB, Bogor. Penelitian bertujuan untuk mengkaji stabilitas produksi beberapa genotipe tomat dan mengetahui faktor yang mempengaruhinya pada kondisi naungan. Hasil penelitian menunjukkan bahwa naungan mempengaruhi hasil dan insiden penyakit pada tanaman tomat. Siklus panen tidak berbeda antara kontrol dengan naungan 50\%. Rata-rata jumlah buah $15-60 \%$ lebih tinggi di bawah naungan 50\% kecuali genotipe Apel Belgia dan Tora yang cenderung menurun. Insiden penyakit virus gemini berkurang $80 \%$ dan tingkat keparahannya menurun sebesar $70 \%$ pada naungan $50 \%$. Namun demikian, bobot hasil per panen seluruh genotipe tomat pada naungan $50 \%$ menurun sebesar $24.1 \%$ yang disebabkan oleh kecenderungan penurunan ukuran buah. Penelitian menunjukkan bahwa stabilitas produksi tomat di bawah naungan dipengaruhi oleh genotipe dan kejadian penyakit. Perlu evaluasi lanjut mengapa kejadian penyakit lebih rendah pada naungan $50 \%$.
\end{abstract}

Kata kunci: agroforestri, anthosianin, serangan penyakit, Solanum lycopersicum, virus gemini

\footnotetext{
${ }^{1}$ Mahasiswa Pascasarjana Departemen Agronomi dan Hortikultura, Fakultas Pertanian, Institut Pertanian

Bogor, Jl Meranti Kampus IPB Darmaga, Bogor 16680, Indonesia

${ }^{2}$ Departemen Agronomi dan Hortikultura, Fakultas Pertanian, Institut Pertanian Bogor

Kampus IPB Darmaga, Bogor 16680, Indonesia

E-mail: edisang@gmail.com (*Penulis korespondensi)
} 


\section{PENDAHULUAN}

Tanaman tomat (Solanum lycopersicum L.) banyak ditanam secara tumpangsari pada sistem agroforestri khususnya di dataran tinggi, seperti di Cianjur (Pranoto, 2013). Sistem tersebut menyebabkan tanaman di bawah tegakan kayu akan menerima intensitas cahaya matahari yang lebih rendah dibandingkan dengan monokultur, akibatnya terjadinya penurunan hasil khususnya pada tanaman suka cahaya (Manurung et al., 2008; Ekawati et al., 2010). Klaim adanya penurunan hasil tersebut juga disampaikan petani (Pranoto, 2013).

Diduga bahwa penurunan produksi dalam sistem tumpangsari tidak semata-mata akibat tanaman kekurangan cahaya atau mengalami stress naungan. Yosepha et al. (2008) dan Rana et al. (2014) menyatakan bahwa pemberian naungan menyebabkan perubahan iklim mikro yang lebih mendukung serangan penyakit yang lebih tinggi. Pendapat berbeda disampaikan Elad et al. (2007) bahwa tanaman cabai cenderung diserang penyakit lebih sedikit jika diberi naungan. Ilić et al. (2011) melaporkan adanya penghematan air irigasi dan peningkatan kualitas cabai (Capsicum annuum L.) yang dinaungi $30-40 \%$. Stabilitas produksi tanaman tomat pada kondisi ternaungi kaitannya dengan gangguan penyakit masih jarang dilaporkan. Salah satu penyakit penting tomat adalah Begomovirus ditularkan kutu kebul (Bemicia tabaci) yang menyerang pertanaman termasuk di Jawa (De Barro et al., 2011; Santoso et al., 2013).

Penggunaan naungan pada tanaman tomat sebenarnya telah banyak dipraktekkan di daerah sub tropis, khususnya untuk mengurangi penyakit sun burn serta untuk meningkatkan hasil dan kualitas buah (Gent, 2007; Kittas et al., 2009; Peet, 2009). Sulistyowati et al. (2016) menyatakan bahwa respon tanaman tomat terhadap naungan dipengaruhi oleh genotipe; hasil tomat dari genotipe suka naungan lebih tinggi pada naungan 50\% dibandingkan dengan tanpa naungan. Penelitian ini bertujuan mengevaluasi stabilitas produksi tanaman tomat di bawah naungan paranet 50\% dibandingkan kontrol, dan kaitannya dengan gangguan penyakit keriting daun oleh Begomovirus yang merupakan penyakit tomat umum di Indonesia. Naungan 50\% dipilih karena salah satu tresh-hold pada sistem agroforestri (Santosa, 2014).

\section{BAHAN DAN METODE}

Penelitian dilaksanakan di Kebun Percobaan Cikarawang, IPB Bogor pada Desember 2016 sampai Maret 2017 dengan jenis tanah Latosol Darmaga. Selama penelitian, rata-rata curah hujan bulanan adalah $282.5 \mathrm{~mm}$. Rata-rata suhu udara harian adalah $28.50{ }^{\circ} \mathrm{C}$, kelembaban udara $70.88 \%$, dan intensitas cahaya 61.24 klux pada kondisi tanpa naungan, sedangkan pada kondisi naungan ratarata suhu udara adalah $27.30{ }^{\circ} \mathrm{C}$, kelembaban udara $73.88 \%$, dan intensitas cahaya 26.72 klux. Lahan percobaan memiliki $\mathrm{pH}\left(\mathrm{H}_{2} \mathrm{O}\right) 5.90$ (agak asam), C-organik $1.44 \%$ (rendah), Ntotal $0.15 \%$ (rendah), Ca 7.73 me.100 g $\mathrm{g}^{-1}$ (sedang), P $1.70 \mathrm{ppm}$ (sangat rendah), dan $\mathrm{K}$ $0.26 \mathrm{mg} .100 \mathrm{~g}^{-1}$ (rendah).

Percobaan disusun dalam petak tersarang (nested design) yang terdiri atas dua faktor. Faktor pertama sebagai petak utama berupa perlakuan naungan yaitu tanpa naungan (kontrol) dan naungan 50\%. Faktor kedua sebagai anak petak yakni enam genotipe tomat yang telah dikelompokkan berdasarkan toleransinya terhadap naungan oleh Sulistyowati et al. (2016), yakni genotipe peka (P) (Tora dan F7005001-4-1-12-5), toleran (T) (F7003008-1-12-10-3 dan F7003008-1-12-162), dan senang naungan (S) (SSH 3 dan Apel Belgia). Perlakuan diulang tiga kali sehingga ada 36 satuan percobaan dengan setiap satuan percobaan ada 60 tanaman.

Bibit tomat umur empat minggu ditanam di bedengan dengan jarak tanam $50 \mathrm{~cm} \times 70 \mathrm{~cm}$ (lebar bedengan $120 \mathrm{~cm}$ dengan lebar guludan $20 \mathrm{~cm}$ ). Naungan $50 \%$ dibuat dengan menggunakan paranet untuk menahan intensitas cahaya sebesar 50\%, sedangkan pada perlakuan kontrol tidak diberi naungan. Paranet dibentangkan sejak sebelum tanam hingga panen. Pupuk majemuk NPK diberikan dengan dosis $800 \mathrm{~kg} \mathrm{ha}^{-1}$ dengan cara dikocor terdiri atas NPK (15-15-15) diberikan selama vegetatif dan NPK (10-55-10) diberikan selama generatif (Subhan et al., 2009). Pemberian pupuk NPK (15-15-15) dilakukan setiap 2 minggu dengan dosis $10 \mathrm{~g} \mathrm{~L}^{-1}$ sejak 2 minggu setelah tanam (MST) hingga 8 MST, sedangkan NPK (10-5510) dengan dosis $2 \mathrm{~g} \mathrm{~L}^{-1}$ diberikan mulai 10-12 MST. Setiap tanaman menerima $200 \mathrm{~mL}$ pada setiap pemberian pupuk. Pemeliharaan tanaman berupa pengendalian hama penyakit dilakukan rutin setiap dua minggu sekali, dan gulma 
dikendalikan secara manual. Penyiraman dilakukan setiap hari, kecuali terjadi hujan deras. Pada saat mulai berbunga, irigasi diberikan 2 kali sehari. Buah dipanen jika 60$90 \%$ bagian berwarna merah dengan jeda panen dua hari.

Variabel pengamatan meliputi bobot buah per tanaman $(\mathrm{g})$, diameter $(\mathrm{cm})$ dan bobot buah (g). Analisis kandungan klorofil a, klorofil $\mathrm{b}$, antosianin dan karotenoid $\left(\mathrm{mg} \mathrm{\textrm {g } ^ { - 1 }}\right.$ daun segar) dilakukan pada 7 minggu setelah tanam (MST) yang diambil pada daun ke 3 dan 4, menggunakan spektrofotometer dengan metode Sims dan Gamon (2002). Thermo-hygrometer dipasang di tengah areal tanpa naungan dan naungan $50 \%$, dan data diambil pada pagi (07:00), siang (13:00), dan sore hari (18:00).

Identifikasi penyebab penyakit dilakukan menggunakan metode Aidawati et al. (2002). Insidensi penyakit dihitung pada 16 minggu menggunakan rumus sebagai berikut: IP $=\frac{n}{N} \times 100 \% ;$ dengan IP adalah insidensi penyakit, $\mathrm{N}$ adalah jumlah tanaman yang sakit, dan $\mathrm{n}$ adalah jumlah tanaman. Keparahan penyakit dihitung dari persentase tanaman bergejala penyakit pada waktu yang sama. Pengelompokan ketahanan genotipe tomat dilakukan menggunakan kriteria ketahanan dari Ganefianti et al. (2008), yaitu tahan, agak rentan, rentan, dan sangat rentan dengan nilai IP berturut-turut $\quad 1 \%<\mathrm{IP} \leq 10 \%, \quad 10 \%<\mathrm{IP} \leq 20 \%$, $20 \%<\mathrm{IP} \leq 40 \%$, IP $>40 \%$, yang merefleksikan gejala ringan, sedang, berat, dan sangat berat.

Identifikasi ketahanan terhadap Begomo virus (tobacco yellow leaf curl virus-TYLCV) mengikuti Ganefianti et al. (2008), dan intensitas gejala penyakit virus dihitung menggunakan rumus dari Dolores (1996) yakni: $\mathrm{I}=\frac{\sum(\mathrm{nxv})}{\mathrm{N} \times \mathrm{V}} \times 100 ;$ I-intensitas gejala serangan, $n$-jumlah tanaman yang termasuk ke dalam skala gejala tertentu, v-nilai gejala tertentu, $\mathrm{N}$-jumlah tanaman yang diamati, Vnilai keparahan gejala tertinggi. Data dianalisis mengunakan uji $\mathrm{F}$ dan jika berbeda nyata dilanjutkan dengan uji LSD pada taraf $\alpha=5 \%$.

\section{HASIL DAN PEMBAHASAN}

\section{Kandungan Klorofil dan Antosianin Daun}

Naungan 50\% meningkatkan kandungan klorofil a, b dan klorofil total (Tabel 1); genotipe tidak menunjukkan adanya perbedaan kandungan klorofil daun. Hasil ini berbeda dengan Niinemets (2010) dan Sulistyowati et al. (2016) bahwa genotipe toleran naungan memiliki kandungan klorofil lebih tinggi pada saat dinaungi dibandingkan genotipe peka. Ada kemungkinan genotipe tanaman tomat memiliki plastisitas fisiologi berbeda terhadap naungan sehingga ada perbedaan hasil penelitian ini dengan penelitian sebelumnya. Plastisitas fisiologi dan fenotipe telah dilaporkan pada Solanaceae dan juga tanaman lain (Putriantari dan Santosa, 2014; Santosa et al., 2018; Yulianti et al., 2018). Pada tanaman leunca (Solanum nigrum L.) plastisitas fenotipe dipangaruhi oleh dosis pupuk nitrogen (Santosa et al., 2017).

Tabel 1 menunjukkan bahwa nisbah klorofil a/b lebih tinggi pada kontrol dibandingkan dengan naungan 50\%. Nisbah tersebut mengindikasikan bahwa pada naungan $50 \%$, laju peningkatan jumlah klorofil a lebih rendah daripada peningkatan kandungan klorofil $b$. Tingginya kandungan total klorofil pada naungan 50\% disebabkan oleh peningkatan sintesis dan menurunnya laju degradasi klorofil, sejalan dengan pendapat Santosa et al. (2000). Peningkatan kandungan klorofil pada naungan 50\% telah banyak dikemukakan peneliti, sebagai salah satu mekanisme adaptasi tanaman pada intensitas cahaya rendah (Kisman et al., 2007). Da Cunha-Chiamolera (2017) menyatakan bahwa pengurangan intensitas cahaya mendorong degradasi klorofil a menjadi klorofil b pada tomat.

Kandungan karoten dan antosianin daun tidak dipengaruhi oleh genotipe dan naungan, maupun interaksinya (Tabel 2). Hasil ini berbeda dengan percobaan Muhuria et al. (2007), bahwa naungan 50\% mengakibatkan peningkatan kandungan antosianin daun kedelai. Menurut Shi et al. (2018), genotipe toleran naungan memiliki kandungan pigmen non kloroplas yang lebih tinggi dibandingkan yang peka dalam rangka meningkatkan kemampuan menangkap radiasi matahari. Fukuoka et al. (2014) menyatakan bahwa pada tanaman Gynura bicolor ditanam dengan cahaya rendah, karoten didegradasi menjadi antosianin sehingga jumlah antosianin meningkat. Tidak adanya perbedaan nyata secara statistik jumlah antosianin pada penelitian ini mengindikasikan bahwa 
metabolisme karoten pada daun tanaman tomat kemungkinan berbeda dengan tanaman Gynura bicolor maupun kedelai.

\section{Hasil Buah}

Naungan tidak nyata mempengaruhi bobot per buah dan diameter buah (Tabel 3). Ukuran buah lebih nyata dipengaruhi genotipe tomat daripada perlakuan naungan. Data tersebut menunjukkan bahwa kapasitas sink buah tomat relatif sama pada kedua perlakuan naungan tersebut pada selang kepercayaan $95 \%$.

Tabel 3 menunjukkan bahwa rata-rata bobot hasil buah per panen per tanaman nyata lebih rendah pada naungan, yaitu $301.85 \pm 112.32 \mathrm{~g}$ pada kontrol menjadi
$229.22 \pm 37.73$ g pada naungan $50 \%$ atau terjadi penurunan produksi sebesar $24.1 \%$. Genotipe Tora memiliki bobot dan diameter buah terbesar, sedangkan genotipe F7003008-1-1216-2 memiliki ukuran yang terkecil di antara genotipe yang diuji. Penelitian ini menunjukkan bahwa pengelompokan genotipe tomat berdasarkan kapasitas produksi seperti yang dilakukan Sulistyowati et al. (2016) belum mewakili keseluruhan sifat tanaman tomat. Dengan kata lain, faktor penentu produksi tomat di bawah naungan kemungkinan besar bukan semata-mata disebabkan oleh keterbatasan cahaya, tetapi ada faktor lain yang diduga berkontribusi terhadap stabilitas produksi tomat di bawah naungan.

Tabel 1. Kandungan klorofil a, klorofil b, klorofil total, dan rasio klorofil a/b dari 6 genotipe tomat dari perlakuan naungan $0 \%$ dan $50 \%$ pada umur $7 \mathrm{MST}$

\begin{tabular}{lcccc}
\hline \multicolumn{1}{c}{ Perlakuan } & $\begin{array}{c}\text { Klorofil a } \\
\left(\mathrm{mg} \mathrm{g}^{-1}\right)\end{array}$ & $\begin{array}{c}\text { Klorofil b } \\
\left(\mathrm{mg} \mathrm{g}^{-1}\right)\end{array}$ & $\begin{array}{c}\text { Klorofil } \\
\text { Total }\end{array}$ & $\begin{array}{c}\text { Nisbah } \\
\text { Klorofil a/b }\end{array}$ \\
\hline Naungan & & & & \\
0\% (kontrol) & $0.44 \pm 0.03 \mathrm{~b}$ & $0.17 \pm 0.01 \mathrm{~b}$ & $0.60 \pm 0.04 \mathrm{~b}$ & $2.63 \pm 0.07 \mathrm{a}$ \\
50\% & $0.51 \pm 0.04 \mathrm{a}$ & $0.20 \pm 0.01 \mathrm{a}$ & $0.71 \pm 0.05 \mathrm{a}$ & $2.47 \pm 0.11 \mathrm{~b}$ \\
Genotipe & & & & \\
$\quad$ Apel Belgia (S) & $0.49 \pm 0.06$ & $0.19 \pm 0.03$ & $0.67 \pm 0.09$ & $2.61 \pm 0.06$ \\
SSH 3 (S) & $0.45 \pm 0.02$ & $0.18 \pm 0.01$ & $0.63 \pm 0.02$ & $2.52 \pm 0.13$ \\
F7003008-1-12-10-3 (T) & $0.48 \pm 0.08$ & $0.19 \pm 0.04$ & $0.67 \pm 0.01$ & $2.65 \pm 0.06$ \\
F7003008-1-12-16-2 (T) & $0.48 \pm 0.07$ & $0.19 \pm 0.03$ & $0.67 \pm 0.10$ & $2.56 \pm 0.07$ \\
Tora (P) & $0.40 \pm 0.10$ & $0.18 \pm 0.04$ & $0.63 \pm 0.14$ & $2.47 \pm 0.07$ \\
F7005001-4-1-12-5 (P) & $0.48 \pm 0.01$ & $0.20 \pm 0.02$ & $0.67 \pm 0.03$ & $2.51 \pm 0.29$ \\
\hline
\end{tabular}

Keterangan : Angka pada kolom yang sama diikuti dengan huruf yang sama pada masing-masing peubah menunjukkan tidak berbeda nyata pada LSD $\alpha=5 \%$. S: senang; T: toleran naungan; P: peka. Rataan \pm SD.

Tabel 2. Kandungan karoten dan antosianin pada 6 genotipe tomat dari perlakuan naungan $0 \%$ dan $50 \%$ pada umur 7 MST

\begin{tabular}{lcc}
\hline \multicolumn{1}{c}{ Perlakuan } & $\begin{array}{c}\text { Karoten } \\
\left(\mathrm{mg} \mathrm{g}^{-1}\right)\end{array}$ & $\begin{array}{c}\text { Antosianin } \\
\left(\mathrm{mg} \mathrm{100} \mathrm{g}^{-1}\right)\end{array}$ \\
\hline Naungan & & \\
0\% (kontrol) & $0.043 \pm 0.001 \mathrm{a}$ & $0.063 \pm 0.020 \mathrm{a}$ \\
50\% & $0.040 \pm 0.001 \mathrm{a}$ & $0.098 \pm 0.052 \mathrm{a}$ \\
Genotipe & & \\
$\quad$ Apel Belgia (S) & $0.042 \pm 0.001 \mathrm{a}$ & $0.061 \pm 0.023 \mathrm{a}$ \\
SSH 3 (S) & $0.045 \pm 0.013 \mathrm{a}$ & $0.091 \pm 0.016 \mathrm{a}$ \\
F7003008-1-12-10-3 (T) & $0.043 \pm 0.001 \mathrm{a}$ & $0.036 \pm 0.001 \mathrm{a}$ \\
F7003008-1-12-16-2 (T) & $0.043 \pm 0.001 \mathrm{a}$ & $0.086 \pm 0.016 \mathrm{a}$ \\
Tora (P) & $0.037 \pm 0.001 \mathrm{a}$ & $0.099 \pm 0.036 \mathrm{a}$ \\
F7005001-4-1-12-5 (P) & $0.042 \pm 0.001 \mathrm{a}$ & $0.111 \pm 0.065 \mathrm{a}$ \\
\hline
\end{tabular}

Keterangan: Angka pada kolom perlakuan yang sama diikuti dengan notasi sama pada masing-masing peubah menunjukkan tidak berbeda nyata pada LSD $\alpha=5 \%$. S: senang; T: toleran naungan; P: peka. Rataan \pm SD. 
Tabel 3. Rata-rata bobot, diameter buah, dan hasil per panen per tanaman pada 6 genotipe tomat dari perlakuan naungan $0 \%$ dan $50 \%$

\begin{tabular}{lccc}
\hline \multicolumn{1}{c}{ Perlakuan } & $\begin{array}{c}\text { Bobot per Buah } \\
(\mathrm{g})\end{array}$ & $\begin{array}{c}\text { Diameter Buah } \\
(\mathrm{mm})\end{array}$ & $\begin{array}{c}\text { Bobot Buah per Panen } \\
\text { per Tanaman }(\mathrm{g})\end{array}$ \\
\hline Naungan & & & \\
$\quad$ 0\% (kontrol) & $26.01 \pm 11.27 \mathrm{a}$ & $35.79 \pm 12.33 \mathrm{a}$ & $301.85 \pm 112.32 \mathrm{a}$ \\
$50 \%$ & $18.66 \pm 10.86 \mathrm{a}$ & $30.58 \pm 12.44 \mathrm{a}$ & $229.22 \pm 37.73 \mathrm{~b}$ \\
Genotipe & & & \\
$\quad$ Apel Belgia (S) & $13.44 \pm 4.20 \mathrm{~cd}$ & $32.71 \pm 3.53 \mathrm{~b}$ & $308.42 \pm 126.69 \mathrm{a}$ \\
SSH 3 (S) & $13.48 \pm 4.50 \mathrm{~cd}$ & $29.25 \pm 3.53 \mathrm{~b}$ & $300.75 \pm 32.68 \mathrm{a}$ \\
F7003008-1-12-10-3 (T) & $18.43 \pm 6.73 \mathrm{bc}$ & $25.80 \pm 7.19 \mathrm{~b}$ & $276.75 \pm 38.18 \mathrm{a}$ \\
F7003008-1-12-16-2 (T) & $10.67 \pm 3.34 \mathrm{~d}$ & $26.49 \pm 2.59 \mathrm{~b}$ & $189.70 \pm 14.45 \mathrm{a}$ \\
Tora (P) & $55.28 \pm 6.50 \mathrm{a}$ & $57.80 \pm 3.21 \mathrm{a}$ & $294.00 \pm 59.39 \mathrm{a}$ \\
F7005001-4-1-12-5 (P) & $22.74 \pm 6.14 \mathrm{~b}$ & $27.07 \pm 2.01 \mathrm{~b}$ & $223.59 \pm 14.47 \mathrm{a}$ \\
\hline
\end{tabular}

Keterangan: Angka pada kolom perlakuan yang sama diikuti dengan huruf yang sama pada masing-masing peubah menunjukkan tidak berbeda nyata pada LSD $\alpha=5 \%$. S: senang; T: toleran naungan; P: peka. Rataan \pm SD.

Baik dengan maupun tanpa naungan $50 \%$, jumlah buah tertinggi diperoleh dari Apel Belgia dan SSH 3 yang dikategorikan sebagai genotipe senang naungan (Tabel 4); kedua genotipe tersebut termasuk kelompok tomat kecil (tomat cerry). Namun demikian, jumlah tertinggi tersebut memiliki respon berbeda terhadap perlakuan naungan. Tabel 4 menunjukkan bahwa jumlah buah total meningkat pada 4 genotipe setelah 5 kali panen dengan perlakuan naungan 50\%; selain genotipe Apel Belgia dan Tora yang menunjukkan penurunan hasil dengan perlakuan tersebut. Kontradiksi yang terjadi pada data jumlah buah pada Tabel 4 dengan bobot hasil pada Tabel 3 dapat dijelaskan dari data ukuran buah. Tabel 3 menunjukkan adanya kecenderungan pada semua genotipe terjadi penurunan ukuran dan bobot individu buah. Jadi, meskipun ada peningkatan jumlah buah, tetapi bobot total per panen per tanaman mengalai penurunan. Penyebab penurunan ukuran dan bobot tomat di bawah naungan, serta penurunan jumlah buah khususnya pada genotipe Apel Belgia dan Tora perlu kajian lebih lanjut. Sebagai catatan, genotipe Tora memiliki ukuran buah besar (tomat salad) berbeda dengan Apel Belgia.

Peningkatan jumlah buah dari tanaman dinaungi 50\% sangat menarik untuk dikaji lebih lanjut. Ada indikasi bahwa naungan menyebabkan fruit set lebih tinggi, sesuai pendapat Gelmesa et al. (2012) bahwa intensitas cahaya rendah mengurangi gugur bunga. Kaitan antara naungan dengan fruit set ini perlu kajian lebih lanjut. Lebih lanjut pada Solanum nigrum L, Santosa et al. (2017) melaporkan bahwa dosis pupuk nitrogen memengaruhi bentuk kanopi yang pada gilirannya memengaruhi hasil buah.

\section{Kejadian Penyakit}

Insiden dan tingkat keparahan penyakit tomato yellow leaf curl virus (TYLCV) yang disebabkan oleh Begomovirus berbeda antara tanaman yang dinaungi dan kontrol (Tabel 5). Tanaman di bawah naungan menunjukkan proporsi gejala penyakit yang lebih rendah. Tanaman terserang menunjukkan gejala daun menguning, tepi daun melengkung, keriting, cupping, ukuran daun mengecil, tulang daun menebal dan tanaman menjadi kerdil. Gejala penyakit tersebut tidak berbeda antar genotipe yang diuji. Berdasarkan kriteria ketahanan genotipe dari Ganefianti (2010), Tora termasuk sangat rentan, Apel Belgia, F7003008-1-12-103, F7003008-1-12-16-2 dan F7005001-4-1-125 termasuk rentan, dan SSH-3 agak rentan.

Tanpa memperhatikan genotipe, insiden penyakit cukup tinggi pada tanaman kontrol yakni $33.80 \%$ dan menurun sebesar $80 \%$ menjadi $6.77 \%$ pada naungan $50 \%$. Penyakit TYLCV ditularkan oleh kutu kebul (Bemisia tabaci) sebagai vektor virus. Naungan 50\% menyebabkan populasi kutu kebul menurun. Jumlah kutu kebul per tanaman yang terserang adalah 0-4 ekor (rata-rata 1.4 ekor) di bawah naungan, sedangkan pada kontrol jumlahnya 
2-7 ekor (rata-rata 4.6 ekor). Penelitian Shi et al. (2018) menunjukkan bahwa jumlah virus pada tanaman tomat hampir sama antara penularan oleh 10 ekor kutu kebul pada 30 hari dengan 5 ekor kutu kebul pada 40 hari dan seekor kutu kebul pada 60 hari setelah infeksi. Hal tersebut mengindikasikan bahwa rendahnya serangan TYLCV pada naungan dalam percobaan ini, lebih disebabkan oleh kemampuan perpindahan kutu kebul dari tanaman ke tanaman, sedangkan pada kondisi tanpa naungan lebih didominasi oleh populasi yang tinggi.

Dengan kata lain, ada perubahan perilaku kutu kebul pada kondisi ternaungi, seperti dikemukakan Sudiono dan Purnomo (2009). Faktor yang memengaruhi insidensi penyakit pada naungan masih belum diketahui. Menurut Ermawati (2010) iklim mikro dan stadia pertumbuhan tanaman memengaruhi insiden penyakit, dan Gunaeni dan Purwati (2013) menduga adanya senyawa toksin yang dihasilkan tanaman akibat stress sehingga preferensi patogen berubah. Hasil pada penelitian ini menunjukkan bahwa peubah yang diduga kuat memengaruhi dinamika insidensi penyakit perlu diamati lebih lanjut.

Tabel 4. Jumlah buah per panen per plot pada 6 genotipe tomat dari perlakuan naungan $0 \%$ dan $50 \%$

\begin{tabular}{|c|c|c|c|c|c|c|}
\hline \multirow{2}{*}{ Genotipe } & \multicolumn{5}{|c|}{ Jumlah Buah Pada Panen Ke- } & \multirow{2}{*}{$\begin{array}{c}\text { Jumlah Total } \\
\text { Buah }\end{array}$} \\
\hline & 1 & 2 & 3 & 4 & 5 & \\
\hline \multicolumn{7}{|c|}{ Naungan 0\% (kontrol) } \\
\hline Apel Belgia (S) & 25.4 & 18.3 & 28.2 & 21.5 & 25.0 & $118.4 \mathrm{a}$ \\
\hline SSH $3(\mathrm{~S})$ & 22.4 & 23.7 & 19.0 & 14.6 & 9.9 & $89.5 \mathrm{a}$ \\
\hline F7003008-1-12-10-3 (T) & 8.2 & 18.4 & 13.7 & 11.4 & 7.9 & $59.6 \mathrm{~b}$ \\
\hline F7003008-1-12-16-2 (T) & 17.0 & 6.2 & 9.7 & 17.3 & 9.8 & $60.0 \mathrm{~b}$ \\
\hline Tora $(\mathrm{P})$ & 5.5 & 6.4 & 5.8 & 4.9 & 5.0 & $27.6 \mathrm{c}$ \\
\hline F7005001-4-1-12-5 (P) & 8.2 & 6.2 & 6.4 & 7.0 & 4.5 & $30.0 \mathrm{c}$ \\
\hline Rataan & 14.5 & 13.2 & 13.8 & 12.8 & 10.4 & 64.2 \\
\hline \multicolumn{7}{|c|}{ Naungan $50 \%$} \\
\hline Apel Belgia (S) & 32.5 & 23.8 & 7.5 & 21.3 & 21.6 & $106.3 \mathrm{a}$ \\
\hline SSH 3 (S) & 20.9 & 26.2 & 23.1 & 23.4 & 23.3 & $116.4 \mathrm{a}$ \\
\hline F7003008-1-12-10-3 (T) & 9.6 & 18.8 & 24.9 & 17.8 & 17.9 & 88.9 a \\
\hline F7003008-1-12-16-2 (T) & 23.0 & 13.1 & 23.0 & 19.7 & 19.4 & $98.4 \mathrm{a}$ \\
\hline Tora $(\mathrm{P})$ & 5.1 & 4.6 & 6.0 & 6.3 & 4.0 & $25.4 \mathrm{c}$ \\
\hline F7005001-4-1-12-5 (P) & 21.0 & 8.4 & 10.5 & 13.3 & 13.1 & $66.5 \mathrm{~b}$ \\
\hline Rataan & 18.7 & 15.8 & 15.8 & 17.0 & 16.6 & $83.7 * *$ \\
\hline Genotipe x Naungan & $*$ & $*$ & $*$ & $*$ & $*$ & $*$ \\
\hline
\end{tabular}

Tabel 5. Insidensi keparahan TYLCV oleh Begomovirus pada 6 genotipe tomat yang ditanam pada perlakuan naungan $0 \%$ dan $50 \%$

\begin{tabular}{lcccc}
\hline \multirow{2}{*}{\multicolumn{1}{c}{ Genotipe }} & \multicolumn{2}{c}{ Insidensi Penyakit (\%) } & \multicolumn{2}{c}{ Keparahan Penyakit (\%) } \\
\cline { 2 - 5 } & $0 \%$ & $50 \%$ & $0 \%$ & $50 \%$ \\
\hline Apel Belgia (S) & $26.7 \pm 8.8 \mathrm{bc}$ & $7.2 \pm 3.3 \mathrm{de}$ & $17.8 \pm 5.9 \mathrm{bc}$ & $9.3 \pm 4.2 \mathrm{bcd}$ \\
SSH 3 (S) & $17.8 \pm 7.7 \mathrm{~cd}$ & $10.0 \pm 4.4 \mathrm{de}$ & $20.7 \pm 5.1 \mathrm{bc}$ & $13.3 \pm 5.9 \mathrm{bcd}$ \\
F7003008-1-12-10-3 (T) & $31.1 \pm 3.8 \mathrm{bc}$ & $8.3 \pm 1.7 \mathrm{de}$ & $22.2 \pm 4.4 \mathrm{~b}$ & $8.2 \pm 1.6 \mathrm{~cd}$ \\
F7003008-1-12-16-2 (T) & $35.6 \pm 5.1 \mathrm{~b}$ & $7.8 \pm 3.5 \mathrm{de}$ & $18.3 \pm 6.7 \mathrm{bc}$ & $9.1 \pm 6.4 \mathrm{~cd}$ \\
Tora (P) & $58.9 \pm 0.9 \mathrm{a}$ & $0.1 \pm 0.0 \mathrm{e}$ & $45.2 \pm 3.4 \mathrm{a}$ & $0.4 \pm 0.1 \mathrm{~d}$ \\
F7005001-4-1-12-5 (P) & $32.8 \pm 9.2 \mathrm{bc}$ & $7.2 \pm 2.5 \mathrm{de}$ & $35.9 \pm 2.3 \mathrm{a}$ & $9.3 \pm 2.8 \mathrm{bcd}$ \\
\hline \multicolumn{1}{c}{ Rataan } & 33.8 & 6.8 & 26.7 & 8.3
\end{tabular}

Keterangan: Angka pada kolom yang sama diikuti huruf sama pada masing-masing peubah menunjukkan tidak berbeda nyata pada LSD $\alpha=5 \%$. S: senang; T: toleran naungan; P: peka. Rataan \pm SD 
Tingkat keparahan penyakit yang dihitung dari satuan plot menunjukkan kisaran nilai $0.44-13.33 \%$ untuk seluruh genotipe dinaungi 50\% dan $17.78-45.19 \%$ pada kontrol. Dengan kata lain, ada penurunan tingkat keparahan penyakit hampir $70 \%$ pada tanaman yang dinaungi. Keparahan tersebut berada pada rentang yang dihadapi petani tomat di Jawa seperti dilaporkan Santoso et al. (2013) yakni keparahan serangan penyakit $51.2 \%$ (rentang kejadian 0-100\%). Penurunan keparahan penyakit pada naungan diduga karena kelembaban mikro yang lebih stabil dan suhu udara yang lebih rendah. Penelitian dasar oleh Mew dan Ho (1977) menunjukkan hubungan erat antara peningkatan suhu dengan peningkatan serangan bakteri tanaman tomat. Suhu udara di bawah naungan pada penelitian ini konsisten 1-2 ${ }^{0} \mathrm{C}$ lebih rendah dan kelembaban udara konsisten 3-4\% lebih tinggi dibandingkan dengan kontrol. Iklim mikro dapat diperbaiki melalui pemangkasan; Gumelar et al. (2014) menyatakan bahwa pemangkasan tunas air tomat menurunkan serangan penyakit layu oleh bakteri dan fusarium menjadi $21 \%$ dibandingkan tanpa pemangkasan yakni 30\%. Kemungkinan lain yang menyebabkan penurunan tingkat keparahan penyakit pada tanaman tomat yang dinaungi adalah penurunan jumlah vektor penyakit, termasuk kemungkinan dinamika penyakit selain TYLCV pada kondisi naungan yang berinteraksi dengan vektor tersebut. Namun pada penelitian ini, jumlah vektor penyakit tidak diamati lebih lanjut.

Penggunaan paranet menurunkan insidensi dan tingkat keparahan penyakit khususnya TYLCV atau yang dikenal sebagai virus gemini. Mengingat serangan virus gemini dapat menyebabkan kegagalan produksi tomat (Anfoka, 2005; Santoso et al., 2013), maka penggunaan naungan dapat menjadi salah satu pendekatan untuk mengurangi penyakit tersebut. Gejala serangan virus sebenarnya sudah mulai terlihat pada awal fase vegetatif dan berlanjut fase generatif dan panen. Tingkat keparahan pada seluruh plot naungan 50\% dari varietas Tora mendekati $0 \%$ (paling tidak parah) atau menurun sangat drastis dari $45.19 \%$ pada kontrol (paling parah). Menurut Ganefianti et al. (2008) tingkat keparahan dapat disebabkan infeksi yang terjadi lebih awal. Shi et al. (2018) menyatakan bahwa keparahan infeksi virus ditentukan oleh jenis kelamin kutu kebul; virus yang berasal dari kutu betina lebih ganas dari pada virus yang ditularkan oleh kutu jantan dan populasi virus pada tanaman tomat tertinggi pada 50-60 hari setelah infeksi. Elad et al. (2007) menyatakan bahwa tingkat keparahan penyakit tergantung pada warna paranet yang digunakan.

Penelitian ini menunjukkan bahwa hasil tomat ada penurunan $24.1 \%$ di bawah naungan $50 \%$ jika dilihat dari komponen hasil tetapi dari jumlah tomat mengalami peningkatan. Mengingat stabilitas komponen hasil menjadi penentu keberhasilan kegiatan tumpangsari atau agroforestri, maka untuk menjawab keluhan petani adanya penurunan hasil tomat perlu dikajian lebih lanjut khususnya genotipe dan teknologi budidaya tomat yang digunakan petani. Upaya untuk meningkatkan hasil pada sistem agroforestri sangat penting, karena hingga saat ini sistem tersebut dianggap sebagai model adaptasi pertanian terhadap perubahan iklim (Santosa, 2014). Untuk itu diperlukan kajian lebih mendalam terkait perubahan iklim mikro di bawah sistem agroforestri hubungannya dengan perilaku vektor penyakit yang kemungkinan juga menentukan produktivitas tanaman tomat agroforestri seperti yang terjadi pada penelitian ini.

\section{KESIMPULAN}

Jumlah buah empat genotipe tomat yakni SSH 3, F7003008-1-12-10-3, F7003008-1-1216-2 dan F7005001-4-1-12-5 meningkat pada perlakuan naungan $50 \%$ dibanding dengan kontrol. Peningkatan jumlah buah tomat sekitar $15-60 \%$, diikuti oleh penurunan insiden penyakit $80 \%$ dan penurunan keparahan penyakit sekitar $70 \%$. Namun demikian, total bobot buah mengalami penurunan $24.1 \%$ pada tanaman yang diberi naungan $50 \%$, yang disebabkan oleh kecenderungan penurunan ukuran buah. Hasil penelitian ini menunjukkan bahwa tanaman tomat potensial sebagai komponen dalam agroforestri, dengan catatan perlunya upaya untuk meningkatkan bobot buah. Untuk mendukung hal tersebut, disarankan untuk dilakukan kajian faktor yang mampu meningkatkan bobot buah pada sistem agroforestri di lapang. 


\section{DAFTAR PUSTAKA}

Aidawati, N., S.H. Hidayat, R. Suseno, S. Sosromarsono. 2002. Transmission of an Indonesian isolate of tobacco leaf curl virus (Gemini virus) by Bemisia tabaci Genn. (Hemiptera: Aleyrodidae). Plant Pathology Journal. 18(5): 231-236.

Anfoka, G.H., M. Abhary, M.K. Nakhla. 2005. Molecular identification of species of the tomato yellow leaf curl virus complex in Jordan. Journal of Plant Pathology. 87(1): 65-70.

Da Cunha-Chiamolera, T.P.L., A.B.C. Filho, D.M.M. dos Santos, F.J.R. Cruz. 2017. Gas exchange, photosynthetic pigments, and growth in tomato: lettuce intercropping. Chilean Journal of Agricultural Research. 77(4): 295-302.

De Barro, P.J., S.S. Liu, L.M. Boykin, A.B. Dinsdale. 2011. Bemisia tabaci: A statement of species status. Annual Review of Entomology. 56(1): 1-19.

Dolores, L.M. 1996. Management of pepper viruses, pp. 334-42. In AVNET-II. Final Workshop Proceeding. AVRDC, Tainan, Taiwan.

Ekawati, R., A.D. Susila, J.G. Kartika. 2010. Pengaruh naungan tegakan pohon terhadap pertumbuhan dan produktivitas beberapa tanaman sayuran indigenous. J. Hort. Indonesia. 1(1): 46-52.

Elad, Y., Y. Messika, M. Brand, D.R. David, A. Sztejnberg. 2007. Effect of colored shade nets on pepper powdery mildew (Leveillula taurica). Phytoparasitica. 35(3): 285-299.

Ermawati, Y. 2010. Budidaya dan Pascapanen Cabai Merah. Balai Pengkajian Teknologi Pertanian. Jawa Tengah.

Fukuoka, N., T. Suzuki, K. Minamide, T. Hamada. 2014. Effect of shading on anthocyanin and non-flavonoid polyphenol biosynthesis of Gynura bicolor leaves in midsummer. HortScience. 49(9): 11481153.
Ganefianti, D.W., S. Sujiprihati, S.H. Hidayat, M. Syukur. 2008. Metode penularan dan uji ketahanan genotipe cabai terhadap Begomovirus. Akta Agrosia. 11(2): 162-169.

Gelmesa, D., B. Abeble, L. Desalegn. 2012. Regulation of tomato (Lycopersicon esculentum Mill.) fruit setting and earliness by gibberellic acid and 2,4dichlorophenoxy acetic acid application. African Journal of Biotechnology. 11(51): 11200-11206.

Gent, M.P.N. 2007. Effect of degree and duration of shade on quality of greenhouse tomato. HortScience. 42: 514-520.

Gumelar, R.M.R., S. H. Sutjahjo, S. Marwiyah, A. Nindita. 2014. Karakterisasi dan respon pemangkasan tunas air terhadap produksi serta kualitas buah genotipe tomat lokal. J. Hort. Indonesia. 5(2): 73-83.

Gunaeni, N., E. Purwati. 2013. Uji ketahanan terhadap tomato yellow leaf curl virus pada beberapa galur tomat. Jurnal Hortikultura. 23(1): 65-71.

Ilić, Z., L. Milenković, M. Đurovka, N. Kapoulas. 2011. The effect of color shade nets on the greenhouse climate and pepper yield. Pp. 529-533. In Proceeding of $46^{\text {th }}$ Croatian and $6^{\text {th }}$ International Symposium on Agriculture, Opatija, Croatia 11-14 November 2011.

Kisman, N. Khumaida, Trikoesoemaningtyas, Sobir, D. Sopandie. 2007. Karakter morfo-fisiologi daun, penciri adaptasi kedelai terhadap intensitas cahaya rendah. Bul. Agron. 35(2): 96-102.

Kittas, C., N. Rigakis, N. Katsoulas, T. Bartzanas. 2009. Influence of shading screens on microclimate, growth and productivity of tomato. Acta Horticulturae. 807: 97-102.

Manurung, G.E.S., A.D. Susila, J. Roshetko, M.C. Palada. 2008. Findings and challenges: Can vegetables be productive under tree shade management in West Java? SANREM-TMPEGS Publication, Virginia. 8(8): 2-17. 
Mew, T.W., W.C. Ho. 1977. Effect of soil temperature on resistance of tomato cultivars to bacterial wilt. Phytopathology. 67: 909-911.

Muhuria, L., K.N. Tyas, N. Khumaida, Trikoesoemaningtyas, D. Sopandie. 2007. Adaptasi tanaman kedelai terhadap intensitas cahaya rendah: Karakter daun untuk efisiensi penangkapan cahaya. Bul. Agron. 34(3): 133-140.

Niinemets, U. 2010. A review of light interception in plant stands from leaf to canopy in different plant functional types and in species with varying shades tolerance. Ecological Resume. 25: 693714.

Peet, M.M. 2009. Physiological disorders in tomato fruit development. Acta Horticulturae. 821: 151-160.

Pranoto, H., M.A. Chozin, H.S. Arifin, E. Santosa. 2013. Analisis karakteristik sosial ekonomi dan keberlanjutan sistem agroforestri di sub Daerah Aliran Sungai Cisokan. Pp 624-629. Dalam Prosiding Seminar Nasional Agroforestri 2013 "Agroforestri untuk Pangan dan Lingkungan yang Lebih Baik". Kerjasama Balai Penelitian Teknologi Agroforestry, Fakultas Pertanian Universitas Brawijaya, ICRAF, Masyarakat Agroforestri IndonesiaCiamis. Malang, 21 Mei 2013.

Putriantari, M., E. Santosa. 2014. Pertumbuhan dan kadar alkaloid tanaman leunca (Solanum americanum Miller) pada beberapa dosis nitrogen. J. Hort. Indonesia. 5(3): 175-182.

Rana, N., M. Kumar, A. Walia, S. Sharma. 2014. Tomato fruit quality under protected environment and open field conditions. International Journal of Bioresource and Stress Management. 5(3): 422-426.

Santosa, E., M.A. Chozin, D. Sopandie, S. Harran. 2000. Toleransi terhadap naungan: Fotosintesis, laju respirasi dan kondukstansi stomata pada tanaman padi gogo. Comm. Agriculturae. 6(1): 1-17.

Santosa, E. 2014. Pengembangan tanaman ilesiles tumpangsari untuk kesejahteraan petani dan kemandirian industri pangan nasional. Risalah Kebijakan Pertanian dan Lingkungan. 1(2): 73-79.

Santosa, E., M. Putriantari, H. Nakano, Y. Mine, N. Sugiyama. 2017. Canopy achitecture, biomass and fruit production of Solanum nigrum L. as determined by nitrogen application. J. Hort. Indonesia. 8(3): 162-170.

Santosa, E., N. Sugiyama, A. Kurniawati, A.P. Lontoh, M. Sari, Krisantini. 2018. Variation in floral morphology of agamosporous Amorphophallus muelleri Blume of natural and gibberellin flowerings. J. Applied Horticulture. 20(1): $15-29$.

Santoso, T.J., S.H. Hidayat, M. Herman, Sudarsono. 2013. Aplikasi teknik polymerase chain reaction (PCR) menggunakan primer degenerate dan spesifik gen $A V I$ untuk mendeteksi begomovirus pada tomat (Lycopersicon esculentum Mill.). J. Hort. Indonesia. 4(3): 140-149.

Shi, X., X. Tang, X. Zhang, D. Zhang, F. Li, F. Yan, Y. Zhang, X. Zhou, Y. Liu. 2018. Transmission efficiency, preference and behavior of Bemisia tabaci MEAM1 and MED under the influence of tomato chlorosis virus. Frontiers in Plant Science. 8: 2271.

Sims, D.A., J.A. Gamon. 2002. Relationship between leaf pigment content and spectral reflectance across a wide range of species, leaf structures and developmental stages. Remote Sense Environment. 81: 337-354.

Subhan, N. Nurtika, N. Gunadi. 2009. Respons tanaman tomat terhadap penggunaan pupuk majemuk NPK 15-15-15 pada tanah latosol pada musim kemarau. J. Hort. 19(1): 40-48. 
Sudiono, Purnomo. 2009. Hubungan antara populasi kutu kebul (Bemisia tabaci) dan penyakit kuning pada cabai di Lampung Barat. Jurnal Hama Penyakit Tanaman Tropika. 9(2): 115-120.

Sulistyowati, D., M.A. Chozin, M. Syukur, M. Melati, D. Guntoro. 2016. Selection of shade tolerant tomato genotypes. Journal of Applied Horticulture. 18(2): 154-159.
Yosepha, S., E. Gal, Y. Offir, D.B. Yakir. 2008. Photoselective shade netting integrated with greenhouse technologies for improved performance of vegetable and ornamental crops. Acta Horticulturae. 797: 75-80.

Yulianti, N., E. Santosa, A.D. Susila. 2018. Production of fruits and leafy vegetables Solanum nigrum Linn under different shade levels. Journal of Tropical Crop Science. 5(2): 64-72. 